\title{
Technology Adoption and Innovation of E-Government in Republic of Iraq
}

\author{
Munadil k.Faaeq ${ }^{1}$, Khaled Alqasa ${ }^{2} \&$ Ebrahim Mohammed Al-Matari ${ }^{3}$ \\ ${ }^{1}$ School of Business Management, Universiti Utara Malaysia, Baghdad University, Malaysia \\ ${ }^{2}$ School of Business Management, Universiti Utara Malaysia, University of Aden, Malaysia \\ ${ }^{3}$ Faculty of Business and Economics, Ammran University, Yemen and Othman Yeop Abdullah Graduate School \\ of Business, University Utara Malaysia, Malaysia
}

Correspondence: Ebrahim Mohammed Al-Matari, Faculty of Business and Economics, Ammran University, Yemen and Othman Yeop Abdullah Graduate School of Business, University Utara Malaysia, Malaysia. E-mail: ibrahim_matri7@yahoo.com

Received: September 19, 2014 Accepted: October 27, 2014 Online Published: December 30, 2014

doi:10.5539/ass.v11n3p135

URL: http://dx.doi.org/10.5539/ass.v11n3p135

\begin{abstract}
Electronic government (EG) refers to a computer application employed in government activities and operations, where both government and the public are enabled to interact and transact online. The practicability of EG has not been largely explored in the context of Iraq, owing to the conflicting activities it has been experiencing in the past few years. Prior to EG adoption, variables have to be examined such as infrastructure, social factors, security, skills, users' behavior etc. The present study aims at examining the related variables that could potentially bar the EG services adoption in Iraq with the help of the Unified Theory of Acceptance and Use of Technology (UTAUT). Three independent variables are examined namely effort expectancy, performance expectancy, and social influence - the influence of these variables on the EG services uses as the dependent variable is examined. The study proposes a quantitative examination of the EG services usage behavior with data gathered from Iraq. The study findings are then discussed.
\end{abstract}

Keywords: information system, electronic government, application, unified theory of acceptance and use of technology (UTAUT)

\section{Introduction}

Electronic government (EG) refers to an electronic application that orients services to the beneficiaries in an expedient and expansive way compared to the traditional services offered by the government. Significant numbers of studies have used UTAUT but no study has employed it to examine the EG adoption among public agencies, particularly in the context of Iraq. Accordingly, the present study adopts this theory to examine EG adoption among Iraqi public agencies.

\section{Electronic Government (EG) in Iraq}

The general scenario in Iraq is such that the country is facing innumerable problems in the fields of education, sciences, health and e-services (Wall, 1995; Kamugisha et al., 2007; Ismail et al., 2009). Currently, Iraq had just gone through several different, beginning in the 1990s with the Gulf War to the latest skirmishes within the country's different factions. Although the consequences of war is still evident in the country, the government of Iraq is aiming to do some developments in the country's infrastructure under which e-government is one of the top priorities (Wall, 1995; UN \& ESCWA, 2007). Specifically, the government plans to enable government-citizen interaction and transactions online in an extensive and expedient manner.

e-Government is expected to transform the traditional access of services into one connected to an online portal where every citizen can log onto anywhere and anytime then require. It is reasonable to state that aside from the infrastructure and financial resources required, the success of the EG project also lies in the resolution of some social issues that can prevent EG adoption in the country. In consistent with the statement of Almutiri (2007), there are distinct factors that influence either the success or the failure of technology implementation, and these factors need determination (Chris, 1957). Accordingly, the present study investigates the factors that drive the success or the failure of EG services adoption in Iraq. 


\section{Unified Theory of Acceptance and Use of Technology (UTAUT)}

A comparison between previously proposed theories and models of user acceptance was studied by Venkatesh et al. (2003) after which, they formulated the Unified Theory of Acceptance and Use of Technology (UTAUT). The theories included in their study included Davis et al.'s (1989) technology acceptance model (TAM), Ajzen's (1991) theory of planned behavior (TPB), Ajzen and Fishbein's (1975) theory of reasoned action (TRA), Taylor and Todd's (1995) combination of TAM and TPB (C-TAM-TPB), Thompson et al.'s (1991) model of PC utilization (MPCU), Roger's (2003) innovation diffusion theory (IDT), Compeau and Higgin's (1995) social cognitive theory (SCT), and finally, Davis et al.'s (1992) motivational model. UTAUT comprise of four predictors of users' behavioral intention and behavior of use; these four factors are performance expectancy, effort expectancy, social influence and facilitating conditions (Venkatesh et al., 2003). Four key factors moderate the relationships between these constructs, behavior intention and behavior of use namely age, gender, voluntariness and experience (Venkatesh et al., 2003). Figure 1 presents the UTAUT model diagram.

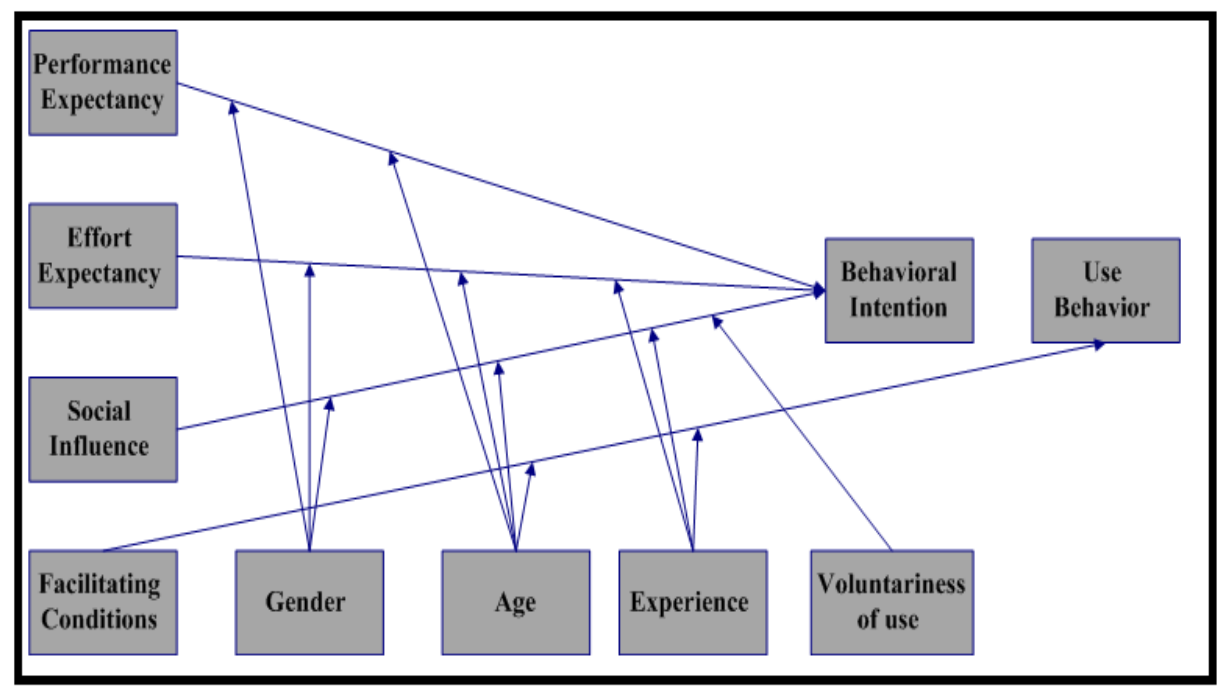

Figure 1. UTAUT Model

This study aims to examine UTAUT in terms of its theoretical perspectives in the context of a developing country, Iraq. The EG adoption is examined while using the UTAUT's theoretical elements in order to establish the examination paradigm as suggested by Venkatesh et al. (2012). In this regard, Alvesson and Karreman (2007) contended that examining theories in novel contexts can lead to opening up new opportunities for the development of new knowledge. UTAUT is the most complex of the innumerable technology adoption and acceptance models owing to its combination of elements from obtained from other models in the hopes of bringing forward a suitable model for the study.

The UTAUT model has been adopted by many studies either partially or wholly and confirmed its validity and reliability in different situations and contexts (e.g. Shao and Siponen, 2011; Slade, Williams and Dwivedi, 2013; Khan et al., 2011). Its employment is therefore justified in the present study.

In the context of developing countries, many studies have investigated the technology use behavior of users and these studies include the works of Al-Awadhi and Morris (2008), Al-Shafi and Weerakkody (2009), Al-Shafi and Weerkoddy, (2010); Nadzar et al. (2011). Specifically, a significant relationship was identified by Venkatesh and Davis (2000) between the successful technology implementation and the behavior of technology use. On a similar finding, Straub (1997) examined the successful implementation of a technology and found it to be proportionate and related to behavioral use. According to Ismail et al. (2009), implementations and technology development is a significant phase.

The UTAUT model is considered to be a universal model used to examine for technology adoption process, particularly when focusing on the user's behavior (Liao and Jr. 2000) as presented in Table 1. The present study is designed to examine EG adoption in the G2C point of view. It focuses on the government terms of EG adoption in terms of transacting with the citizens. e-Government adoption has several benefits to the citizens including renewal of driver's license, payment of summons, Q card (key card), registration and applying for international passports, and death and birth registration (based on the governmental services enumerated by Carter and Belanger, 2004). 
Table 1. Studies using UTAUT variable framework

\begin{tabular}{|c|c|c|c|}
\hline Reference/country & Research using & UTAUT/UTAUT2 & Research Focus \\
\hline $\begin{array}{l}\text { 1-(Venkatesh, et al. } \\
\text { (2003) U.S. }\end{array}$ & $\begin{array}{l}\text { User Acceptance Of Information } \\
\text { Technology: Toward A Unified View }\end{array}$ & UTAUT & $\begin{array}{l}\text { Performance } \\
\text { expectancy } \\
\text { (EE), Soctancy(PE), Influence(SI), } \\
\text { Facilitating Conditions(FC), Behaviour } \\
\text { Intention (BI), Use Behaviour (UB), Gender, } \\
\text { Age, Experience, Voluntarines of use. }\end{array}$ \\
\hline $\begin{array}{l}\text { 2-Yu-Lung et al. (2007) } \\
\text { (Taiwan) }\end{array}$ & $\begin{array}{l}\text { Using UTAUT to explore the } \\
\text { behaviour of } 3 \mathrm{G} \text { mobile } \\
\text { communication users }\end{array}$ & UTAUT & $\begin{array}{l}\text { PE, EE, SI, FC, Use behaviour, Gender, Age, } \\
\text { experience, voluntariness of use, level of } \\
\text { education Intention to Use. }\end{array}$ \\
\hline $\begin{array}{l}\text { 3-Chiu and Wang, (2008) } \\
\text { ( Taiwan) }\end{array}$ & $\begin{array}{l}\text { Understanding Web-based learning } \\
\text { continuance intention: The role of } \\
\text { subjective task value }\end{array}$ & UTAUT & $\begin{array}{l}\text { PE, EE, SI ,FC, } \\
\text { self-efficacy, Attainment } \\
\text { value,intrinsic, anxiety, (CI) }\end{array}$ \\
\hline $\begin{array}{l}\text { 4- Liu, G., et al. (2008) } \\
\text { (China) }\end{array}$ & $\begin{array}{l}\text { User acceptance of Internet banking } \\
\text { in an uncertain and risky environment }\end{array}$ & UTAUT & $\begin{array}{l}\text { Self-efficacy (SF) perceived risk (PR) Locus } \\
\text { ofcontrol(C) } \\
\text { perceived uncertainty (UC) } \\
\text { system quality (SQ) information quality (IQ ) } \\
\text { service quality(VQ), PE }\end{array}$ \\
\hline $\begin{array}{l}\text { 5-Al-Shafi } \quad \text { and } \\
\text { Weerakkody, } \\
\text { (Qatar) }\end{array}$ & $\begin{array}{l}\text { Understanding Citizens' Behavioural } \\
\text { Intention In The Adoption Of } \\
\text { E-Government Services In The State } \\
\text { Of Qatar }\end{array}$ & UTAUT & $\begin{array}{l}\text { PE, EE, SI, Behavioural Intention to Use EG, } \\
\text { Gender, Age, Internet }\end{array}$ \\
\hline $\begin{array}{l}\text { 6-Wang and Shih, (2009) } \\
\text { ( Taiwan) }\end{array}$ & $\begin{array}{l}\text { Why do people use information } \\
\text { kiosks? A validation of the Unified } \\
\text { Theory of Acceptance and Use of } \\
\text { Technology }\end{array}$ & UTAUT & PE, EE, SI, FC, UB, Gender, Age, BI. \\
\hline $\begin{array}{lr}\text { 7-Al-Shafi } & \text { and } \\
\text { Weerakkody } & (2010) \\
\text { (Qatar) } & \\
\end{array}$ & $\begin{array}{l}\text { Factors Affecting E-Government } \\
\text { Adoption In The State Of Qatar }\end{array}$ & UTAUT & $\begin{array}{l}\text { PE, EE, SI, FC, Trust of the Internet, Trust of } \\
\text { Intermediary (BI) and Use Behaviour }\end{array}$ \\
\hline $\begin{array}{l}\text { 8-Yahya et al.(2011) } \\
\text { (Malaysia) }\end{array}$ & $\begin{array}{l}\text { Determinants of UTAUT in } \\
\text { Measuring User Acceptance of } \\
\text { E-Syariah Portal in Syariah Courts in } \\
\text { Malaysia }\end{array}$ & UTAUT & PE, EE, SI, BI, Actual Usage(AU) \\
\hline $\begin{array}{l}\text { 9-Al-Sobhi et al. (2011) } \\
\text { (Saudi Arabia) }\end{array}$ & $\begin{array}{l}\text { The Roles Of Intermediaries In } \\
\text { E-Government Adoption: The Case } \\
\text { Of Saudi Arabia }\end{array}$ & UTAUT & $\begin{array}{l}\text { PE, EE, SI, FC, Trust of the } \\
\text { Internet, Trust of Intermediary, (BI) and Use } \\
\text { Behaviour }\end{array}$ \\
\hline $\begin{array}{l}\text { 10-Abdul-Rahman et al. } \\
\text { (2011) (Malaysia) }\end{array}$ & $\begin{array}{l}\text { Intention to Use Digital Library based } \\
\text { on Modified UTAUT Model: } \\
\text { Perspectives of Malaysian } \\
\text { Postgraduate Students }\end{array}$ & UTAUT & $\begin{array}{l}\text { Information Quality, PE, EE } \\
\text { Service Quality, User Characteristics, Intention } \\
\text { to Use Digital Library }\end{array}$ \\
\hline
\end{tabular}

\section{Research Framework}

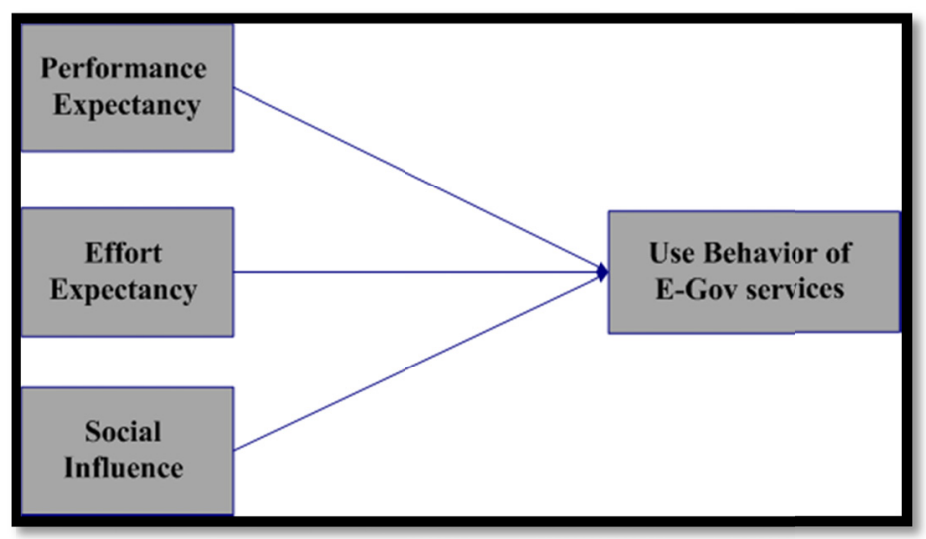

Figure 2. Research framework of EGadoption in Iraq

Researchers applied UTAUT components on a theoretical basis and found it to be successful among technology and innovation usage (e.g. Ally \& Gardiner, 2012; Shao \& Siponen, 2013). This makes UTAUT as a suitable model to be employed as the study frame for the Iraqi EG services in the current research. Detailed information concerning the study model are provided in this section. 
The use of UTAUT in this study is justified by the fact that it is a current model proposed by Venkatesh et al. (2003) in the field of IS and new innovation. The usage behavior of EG services construct was measured with the help of four items adopted from Rahman et al. (2008) and Almajali (2011), PE was measured by six items adopted from Adulwahab and Dahalin (2011) and Venkatesh (2003), EE and SI items were obtained from Adulwahab and Dahalin (2011) and Venkatesh et al. (2003). In addition to this, age, gender, education and experience were not included for model simplification (Maldonado et al., 2011; Wang \& Yang, 2005). Figure 2 presents the current study model.

\section{Research Hypotheses Development}

The UTAUT posits that performance expectancy, effort expectancy and social influence determine behavioral use of EG services in the context of Iraq. With all the variables and hypotheses proposed on the basis of UTAUT, the researcher presents the hypotheses as follows;

H1: Performance expectancy has a positive effect on usage behavior towards EG services.

$\mathrm{H} 2$ : Effort expectancy has a positive effect on usage behavior towards EG services.

H3: Social influence has a positive effect on usage behavior towards EG services.

\section{Research Methodology}

\subsection{Population and Sampling}

This study covers the G2C social and economical government services. For the purpose of this study Iraqi citizens from various demographical levels in three Iraqi regions (south, middle and north) participated in completing the survey, out of which 75 questionnaire were considered as valid responses.

\subsection{Sampling Profile}

The final study sample comprised staff of public universities including lecturers and administrations. Based on the sampling profile, the sample represents the population under study based on different demographic variables and differences were found among the variables. In particular, the respondents were categorized based on eight demographic variables (age, gender, marital status, current occupation, residential area, education, income and Internet usage experience).

Table 2. Participant's demographic information

\begin{tabular}{llll}
\hline Demographic Variable & Category & $(N=75)$ Frequency & Percentage\% \\
\hline Gender & Male & 36 & 48 \\
& Female & 39 & 52 \\
\hline Age & $\leq 22$ & 5 & 6.7 \\
& $23-35$ & 27 & 36.0 \\
& $36-45$ years & 24 & 32.0 \\
& $46-55$ & 16 & 21.3 \\
& $\geq 56$ & 3 & 4.0 \\
\hline Marital status & Single & 22 & 29.3 \\
& Married & 51 & 68.0 \\
& Divorced & - & - \\
& Widowed & 2 & 2.7 \\
\hline Current Occupation & Lecturer & 26 & 24.7 \\
& Manager & 14 & 18.7 \\
& Officer & 26 & 34.7 \\
& Clerks & 6 & 8.0 \\
& Others & 3 & 4.0 \\
\hline Residential Area & City/Urban & 54 & 72.0 \\
& Rural & 21 & 28.0 \\
\hline Education level & PhD & 18 & 24.0 \\
& Master & 19 & 25.3 \\
& Bachelor & 26 & 34.7 \\
& Diploma & 9 & 12.0 \\
& Secondary School & 2 & 2.7 \\
& Read and Write & 1 & 1.3 \\
\hline
\end{tabular}




\section{Data Analysis}

The PLS modeling was used in the analysis of the obtained data from the sample. The PLS, or Partial Least Squares modeling was proposed by Herman Wold $(1982,1985)$ (as cited in LohmLoller, 1987, 1989), in the aspects of LVPLS software computation. As such, the software's theoretical developments were related to Wold (1982, 1985), whereas the enhanced validation methods were attributed to Chin (1998 2001) and Chin and Newsted (1999).

The PLS-Graph software consists of the Lohms Loller's program PLSX for units $\mathrm{x}$ variables data as its core and it enables options. The PLS modeling has to be employed in the first phase of theoretical development for the assessment and validation of exploratory models. In addition to this, among the many features that are unique, is its prediction-oriented aspect, where the methodology allows researchers to focus on the explanation of endogenous constructs, where all the items are gauged via a seven-point scale.

The PLS path modeling method is extensively employed for the estimation of causal relationships in the field of path models that require the indirect measurements of latent constructs by several indicators. Previous studies (Wold, 1982; Lohmoller, 1989; Chin, 1989; Tenenhaus, Vinzi, Chatelin, \& Lauro, 2005) highlighted the basis of methodology for the purpose of evaluating the outcome and they proposed some methodological instances.

\subsection{Testing the Measurement Model, Outer Model via PLS Approach}

Before the hypotheses were tested, the model in term of measurement model and outer model was examined through PLS-SEM method. The present study made use of a two-stage approach brought forward by Anderson and Gerbing (1988). Figure 3 presents the study model along with its structural dimensions.

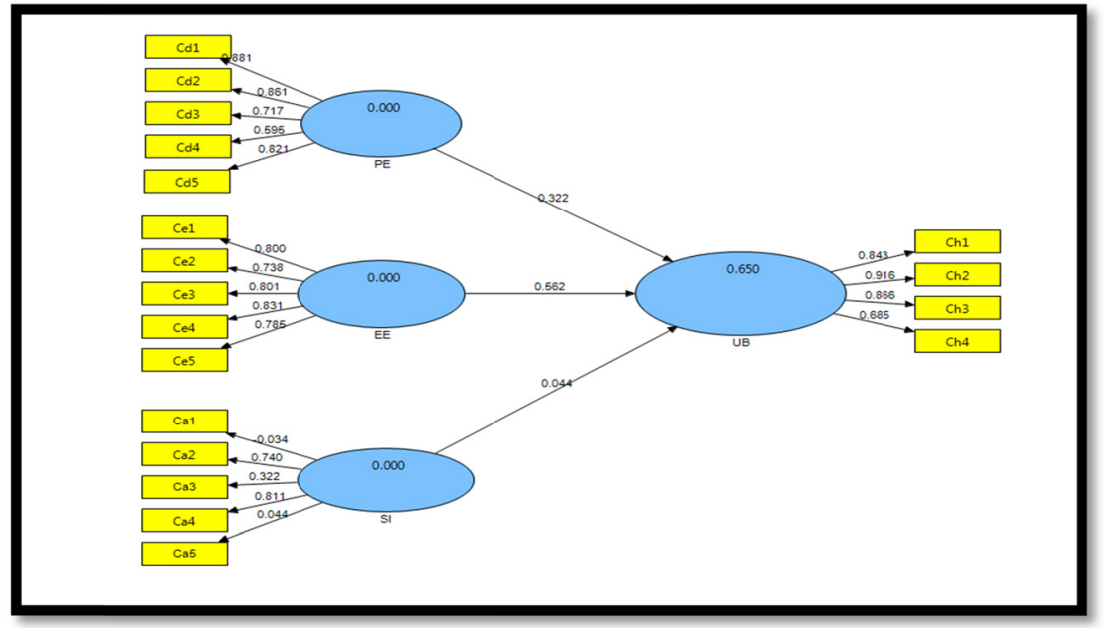

Figure 3. Factor loadings before deletion of items less that loaded less than 0.7

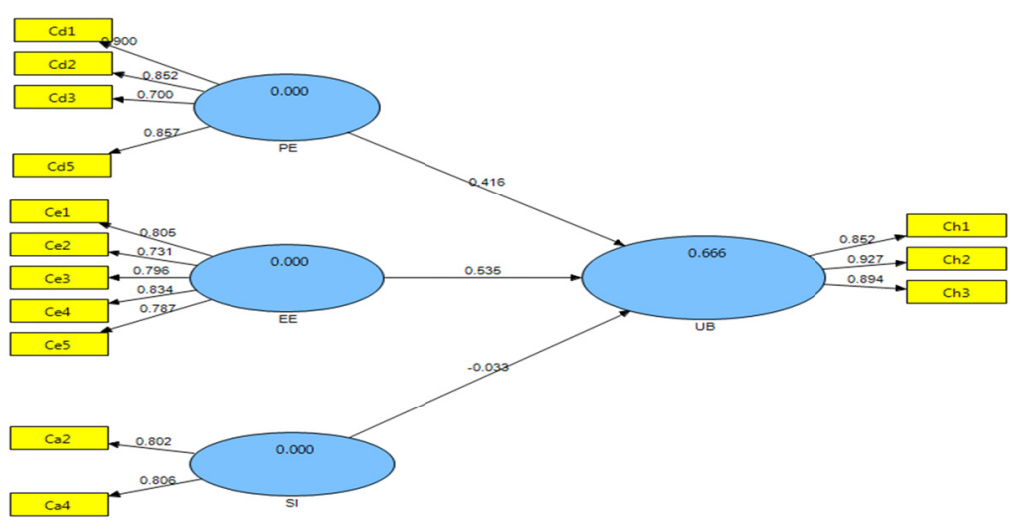

Figure 4. Factor loadings after deletion of items that loaded less than 0.7 


\subsection{Content Validity}

The content validity of a measure refers to the level to which the items measure the concept they are created to measure (Hair et al., 2010). In this regard, the items created to measure a construct should produce higher loading on their construct in comparison to other constructs. In particular, individual item loadings higher than 0.70 are deemed adequate as recommended by Fornell and Larcker (1981). Item loadings are presented in Figures 3 and 4.

The researcher ensured the item loading adequacy by conducting an extensive review of literature to generate items whose validity has already been tested and confirmed. Based on factor analysis, items of constructs and their results are listed in Tables 4 and 5. It is evident from the tables that content validity of items and measures are listed in two ways - first items presenting high loading on their respective constructs are compared to other constructs, and second, significant item loadings on their respective constructs confirms the content validity of measures (see Table 4) as suggested by Chow and Chan, 2008.

Table 4. Significance of factor loadings

\begin{tabular}{lcccc}
\hline & SI & PE & EE & UB \\
\hline CaSI2 & $\mathbf{0 . 8 0 2}$ & 0.406 & 0.252 & 0.295 \\
CaSI4 & $\mathbf{0 . 8 0 6}$ & 0.518 & 0.236 & 0.297 \\
CdPE1 & 0.544 & $\mathbf{0 . 9 0 0}$ & 0.414 & 0.606 \\
CdPE2 & 0.550 & $\mathbf{0 . 8 5 2}$ & 0.478 & 0.570 \\
CdPE3 & 0.389 & $\mathbf{0 . 7 0 0}$ & 0.434 & 0.471 \\
CdPE5 & 0.418 & $\mathbf{0 . 8 5 7}$ & 0.414 & 0.589 \\
CeEE1 & 0.215 & 0.414 & $\mathbf{0 . 8 0 5}$ & 0.556 \\
CeEE2 & 0.157 & 0.353 & $\mathbf{0 . 7 3 1}$ & 0.492 \\
CeEE3 & 0.126 & 0.327 & $\mathbf{0 . 7 9 6}$ & 0.533 \\
CeEE4 & 0.395 & 0.524 & $\mathbf{0 . 8 3 4}$ & 0.694 \\
CeEE5 & 0.257 & 0.411 & $\mathbf{0 . 7 8 7}$ & 0.626 \\
ChUB1 & 0.231 & 0.571 & 0.604 & $\mathbf{0 . 8 5 2}$ \\
ChUB2 & 0.410 & 0.672 & 0.669 & $\mathbf{0 . 9 2 7}$ \\
ChUB3 & 0.335 & 0.561 & 0.709 & $\mathbf{0 . 8 9 4}$ \\
\hline
\end{tabular}

Table 5. Results of convergent validity analysis

\begin{tabular}{llllll}
\hline Construct & Item & $\begin{array}{l}\text { Cronbach's } \\
\text { Alpha }\end{array}$ & $\begin{array}{l}\text { Factor } \\
\text { Loadings }\end{array}$ & $\begin{array}{l}\text { composite } \\
\text { Reliability }\end{array}$ & AVE \\
\hline Social Influence & CaSI2 & 0.453 & 0.802 & 0.785 & 0.647 \\
Performance Expectancy & CaSI4 & & 0.806 & & 0.898 \\
& CdPE1 & 0.847 & 0.900 & & \\
& CdPE2 & & 0.852 & & \\
& CdPE3 & & 0.700 & & \\
Effort Expectancy & CdPE5 & & 0.857 & \\
& CeEE1 & 0.852 & 0.805 & 0.893 & \\
& CeEE2 & & 0.731 & & \\
& CeEE3 & & 0.796 & & \\
& CeEE4 & & 0.834 & & \\
Usage Behavior & CeEE5 & & 0.787 & \\
& ChUB1 & 0.871 & 0.852 & 0.921 & \\
& ChUB2 & & 0.927 & & \\
\hline
\end{tabular}

\subsection{Discriminant Validity of Measures}

The next step after confirming the construct validity of the outer model entails the confirmation of the discriminant validity. This is considered as a compulsory phase prior to testing of hypotheses through path analysis. The discriminant validity of measures displays the level to which the items differentiate among constructs - in other words, it shows that the items make use of different non-overlapping constructs. Thus, 
although there is correlation among constructs, they are measured with the help of distinct concepts as explained by Compeau et al. (1999). According to him, in cases where the discriminant validity of the measure is confirmed, the variance shared between every constructs and its measures should be greater compared to the variance shared among the constructs.

In this study, the discriminant validity of the measures was confirmed through the method employed by Fornell and Larcker (1981). The square root of average variance extracted (AVE) of the entire constructs positioned at the correlation matrix diagonal elements are presented in Table 6. Discriminant validity is confirmed by the greater value of the diagonal elements in comparison to other elements in the role and column where they are positioned. Following this confirmation, the hypotheses testing results are expected to be valid and reliable.

Table 6. Discriminant validity analysis

\begin{tabular}{lllll}
\hline & EE & PE & SI & UB \\
\hline EE & $\mathbf{0 . 7 9 1}$ & & & \\
PE & 0.521 & $\mathbf{0 . 8 3 1}$ & & \\
SI & 0.304 & 0.575 & $\mathbf{0 . 8 0 4}$ & $\mathbf{0 . 8 9 2}$ \\
UB & 0.742 & 0.676 & 0.368 & \\
\hline
\end{tabular}

The statistical significance of the path coefficients was confirmed in this study through the bootstrapping method in the SmartPLS 2.0. The method involves the production of $\mathrm{T}$ values of every path coefficient along with the $\mathrm{P}$ values as shown in Table 7. The results provide interesting results that extend those of the prior studies regarding e-services.

Table 7. Results of the Inner Structural Model

\begin{tabular}{ccccccc}
\hline Hyp. No. & Hypothesis Statement & Path Coefficient & Standard Error & T Value & P Value & Decision \\
\hline H1 & EE -> UB & $0.535^{* * *}$ & 0.084 & 6.391 & 0.000 & Supported \\
H2 & PE -> UB & $0.416^{* * *}$ & 0.112 & 3.707 & 0.000 & Supported \\
H3 & SI -> UB & -0.033 & 0.079 & 0.422 & 0.337 & Not Supported \\
\hline
\end{tabular}

$*: \mathrm{p}<0.1 ; * * \mathrm{p}<0.05 ; * * * \mathrm{p}<0.01$

\section{Study Findings}

In practice, the study findings will contribute to the Iraqi government's decision throughout the implementation and adoption of EG services. Empirically, the findings provide evidence to the Iraqi decision makers, IT practitioner, and relevant entities concerning the EG adoption in Iraq. This is particularly pertinent to the country as over 28 million Iraqi citizens have been waiting for the application of such innovation in the country. Detailed study findings are elaborated in the next sections.

\subsection{Effort Expectancy (EE) Has a Positive Influence on Usage Behavior towards E-Services}

Effort expectancy refers to the level of ease related to the system use (Venkatesh et al., 2003, 2011 and 2012). On the basis of prior studies, EE is significant in various innovations in different countries (e.g. Abdul-Rahman et al., 2011; Al-Sobhi et al., 2011; Foon \& Fah, 2011; Venkatesh et al., 2011; Yahya et al., 2011). Nevertheless, EE has not been examined in a situation characterized by violence and danger. Further research is therefore required to examine the relationship between EE and UB in the context of Iraq. Based on the study findings, EE impacts UB (usage behavior) towards EG services in Iraq as they are considered to be easy to understand and employ. The present study, tested the relationship between the two variables found $U B(\beta=0.535, t=6.391, p>0.1)$ indicating that EE significantly and positively influences $\mathrm{UB}$ and that $\mathrm{H} 1$ is supported. This finding is consistent with that of Yu-Lung et al. (2007) who revealed a positive and significant relationship between the two variables.

\subsection{Performance Expectancy (PE) Has a Positive Influence on Usage Behavior towards EG Services}

Performance expectancy (PE) refers to the level to which an individual is convinced that system use will assist him in attaining life performance (Venkatesh et al., 2003, 2012). PE was examined in various fields in literature and included in several software analysis such as SPSs, AMOS and PLS, in different developing as well as 
developed countries (e.g. Al-Shafi \& Weerakkody, 2010; Al-Sobhi et al., 2011; Venkatesh et al., 2003; Venkatesh et al., 2012; Yu-Lung et al., 2007; Yahya et al., 2011).

In this study, the researcher focused on the way in which PE affects UB of EG services among Iraqi users.

To this end, the SEM Analysis results of the relevant hypothesis proposing the relationship between PE and UB showed a significant impact of PE on UB at 0.01 significance level $(\beta=0.416, t=3.707, p<0.01)$, indicating support for H2. According to the findings, individual performance in terms of performances and task accomplishments can be enhanced through the use of EG services.

This result is consistent with those reported by Al-Shafi and Weerakkody (2010), Al-Sobhi et al. (2011) and Lawan (2011) who revealed a positive relationship between PE and the other variables

\subsection{Social Influence Has a Positive Influence on UB towards EG Services}

Low usage of e-services can be generally attributed to social influence (Al-Majali, 2011) and specifically to Iraq. Prior studies have overlooked the examination of the effects of social influence (family and peers) in the context of Iraq.

In light of the hypotheses developed concerning SI, the SEM analysis results indicate that SI has no effect on UB $(\beta=-0.033, \mathrm{t}=0.422, \mathrm{p}>0.1)$ towards EG where $\beta$ was found to have a negative sign $(-0.033)$. This shows that $\mathrm{H} 3$ is rejected.

According to prior studies, SI should have a key role in new innovation but in the present study, the relationship between SI and UB was found to be an insignificant negative correlation and thus H3 is not supported.

This particular result indicates that EG service users are not influenced by any group in their use of EG services. This validates the non-significance of including social influence in the assessment of technology, particularly those used by the public as contended by Chiu and Wang (2008) and Al-Sobhi et al., 2011). This result is consistent with those of other studies who reported no significant relation between SI and UB in the context of Saudi Arabia (Al-Sobhi et al., 2011; Alshehri et al., 2012).

\section{Conclusion}

The present study findings support the contention that mixed findings stem from different countries characterized by different culture, sample sizes, nations, economic, environment and political situations. The main contribution of the study is its examination of the phenomenon in a new environment, namely Iraq. This aspect of the study is particularly significant as UTAUT and usage issues have largely been ignored in this context.

The study findings are expected to contribute to the government bodies in their decisions to adopt EG technology.

\section{Suggestions for Future Research}

Investigating the usage behavior towards technology among the Middle-Eastern region that is rife with challenges and wars (e.g. in Iraq, Yemen, Egypt and Libya) is a significant undertaking. Accordingly, the present study examines the EG explicitly in a risky environment in terms of Government to Citizen (G2C) services. Future studies could focus on Government to Government, Government to Employee, and Government to Business aspects. It is evident that variables affecting usage behavior and user satisfaction has not yet been largely explored in specific contexts. Hence, the need exists to explore such variables in different contexts future research could measure e-banking, e-commerce, e-learning, e-system, e-health record, e-ticket, key card, Q card, smart card, visa card, master card, computer/iPad adoption, mobile government adoption, telecenterservices adoption and acceptance in both developed as well as developing countries, with different cultures, and to employ various sample sizes.

\section{References}

Abdul-Rahman, A. L., \& Jamaludin, A. et al. (2011). Intention to Use Digital Library based on Modified UTAUT Model: Perspectives of Malaysian Postgraduate Students. World Academy of Science, Engineering and Technology, 75 .

Adulwahab, L., \& Dahalin, Z. M. (2011). Effectiveness of Telecentre using a Model of Unified Theory of Acceptance and Use of Technology (UTAUT): Structral Equation Modeling Approach. Emeging Trends in Computing and Information Sciencess, 2(9).

AlAwadhi, S., \& Morris, A. (2008). The use of the UTAUT model in the adoption of e-government services in Kuwait. Proceedings of the 41st Annual Hawaii International Conference on System Sciences, January 7-10, 
2008, Waikoloa, Hawaii (p. 219).

Al-Majali, M. M. (2011). The Antecedents Of Internet Banking Service Adoption In Jordan: Using Decomposed Theory of Planned Behaviour Universiti Ut Ara Malaysia Doctor Of Philosophy.

Alrawashdeh, T. A. (2011). The Extended Utaut Acceptance Model Of Computer Based Distance Training System Among Public Sector's In Jordan. Doctor of Philosoph, UUM, Kedah.

Al-Shafi, S., \& Weerakkody, V. (2009). Understanding Citizens' Behavioural Intention in the Adoption of E-Government Services in the State of Qatar. 1618-1629.

Alsohybe, N. T. (2007). The implementation of e-government in the republic of yemen: An empirical evaluation of the technical and organizational readiness. Capella University.

Alvesson, M., \& Karreman, D. (2007). Constructing mystery: Empirical matters in theory development. Academy of Management Review, 32(4), 1265-1281.

Al-Zoubi, M., \& Sam, T. L. et al. (2011). E-GovernmentAdoption Among Businesses in Jordan. Academic Research International, (1), 141-156.

Borgatti, S. P. (1999). Elements of Research.

Carlsson, C., \& Carlsson, J., et al. (2006). Adoption of Mobil Device/services -searching for Answers with the UTAUT.Hawaii International Conference on System Sciences. Hawaii International Conference on System Science, Hawaii, IEEE.

Chiu, C. M., \& Wang, E. T. G. (2008). Understanding Web-based learning continuance intention: The role of subjective task value. Information \& Management, (45), 194-201. http://dx.doi:101016/j.im2008.02.003

Compeau, D. R., \& Higgins, C. A. (1995). Computer Self-Efficacy: Development of a Measure and Initial Test. MIS Quarterly, 19(2), 189-211.

Davis, F. D., \& Bagozzi, R. P., et al. (1989). User Acceptance of Computer Technology : A comparison of two theoretical models. Management Science, 35(8), 982-1003.

Davis, F. D., \& Bagozzi, R. P., et al. (1992). Extrinsic and Intrinsic Motivation to Use Computers in the Workplace1. Journal of Applied Social Psychology, 22(14), 1111-1132.

Ebrahim, Z., \& Irani, Z. (2005). E-government adoption:architecture and barriers. Business Process Management, 11(5), 589-611.

Fishbein, M., \& Ajzen, I. (1975). Belief, Attitude, Intention, and Behavior: An Introduction to Theory and Research. Reading, MA: Addison-Wesley.

Foon, Y. S. \& Fah, B. C. Y. (2011). Internet Banking Adoption in Kuala Lumpur: An Application of UTAUT Model. International Journal of Business and Management, 6(4), 161-167.

Genuardi, P. (2004). User adoption of information technology: Implications for application development research (Masters Thesis, Faculty of the Graduate School of Arts and Sciences of Georgetown University, Washington, D.C).

HIIK. (2008). Conflict barometer. Heidelberg Institute For International Conflict Research, Department of Political Science, University of Heidelberg.

Igbaria, M. (1992). An examination of microcomputer usage in Taiwan. Information \& amp. Management, 22(1), 19-28. http://dx.doi: 10.1016/0378-7206(92)90003-x

Jain, V., \& Kesar, S. (2011). E-government implementation challenges at local level: A comparative study of government and citizens' perspectives. Electron. Government, Int. J., 8, 208-225. Retrieved from http://www.inderscience.com/inf o/inarticle.php?artid=39837

K.Faaq, M., Ismail, N. A., Osman, W. R. S., K.Faieq, A., \& Aleqab, M. (2009). Application of TAM in the readiness for E-Government services.

Khan, G. F. (2010). Essays on Electronic Government in Developing Countries: A Socio-Technical Perspective. $\mathrm{Ph}$. D, KAIST.

Khan, G. F., \& Moon, J., et al. (2010). Civil Conflict, Digital Divide, and E-government Service Adoption: A Conflict Theory Approach. World Academy of Scienece, Engineering and Technology, 66.

Khan, G. F., Moon, J., Rhee, C., \& Rho, J. J. (2010). E-government Skills Identification and Development: Toward a Staged-Based User-Centric Approach for Developing Countries. Asia Pacific Journal of 
Information Systems, 20(1).

Khan, G. F., Moon, J., Zo, H., \& Rho, J. J. (2012). E-government Service Use Intention: Digital Divide and Technology Adoption in a War-torn Country Information Development.

Lai, V. S., \& Li, H. (2005). Technology acceptance model for internet banking: An invariance analysis. Information and amp; Management, 42(2), 373-386. http://dx.doi: 10.1016/j.im.2004.01.007

Lee, J.-K., Braynov, S., \& Rao, R. (2003). Effects of Public Emergency on Citizens' Usage Intention Toward E-Government: A Study in the Context of War in Iraq. Paper presented at the International Conference on Information Systems (ICIS).

Maldonado, U. P. T., Khan, G. F., Moon, J., \& Rho, J. J. (2011). E-learning motivation and educational portal acceptance in developing countries. Online Information Review, 35(1), 66-85. http://dx.doi/10.1108/ 14684521111113597

Moore, G. C., \& Benbast, I. (1991). Development of an instrument to measure the perceptions of adopting an information technology innovation. Information Systems Research, 2(2), 192-222.

Norman, P., \& Smith, L. (1995). The Theory of Planned Behavior and Exercise: An Investigation into the Role of Prior Behavior, Behavioral Intentions and Attitude Variability. European Journal Social Psychology, 25(4), 403-415.

Ok, S., \& Shon, J. (2008). The Determinant of Internet Banking Usage Behavior in Korea: A Comparison of Two Theoretical Models. Retrieved December 20, 2008, from http://www.collecter.org/archives/2006 December/08.pdf

Paris, Landrigan, P. J., Lioy, P. J., Thurston, G., Berkowitz, G., \& Chen, L. C. (2004). Health and environmental consequences of the world trade center disaster. Environ. Health Perspect., 112, 731-739.

Partridge, H. (2007). Redefining the digital divide: Attitudes do matter! Proceedings of the American Society for Information Science and Technology, 44(1), 1-13.

Pedersen, D. (2002). Political violence, ethnic conflict, and contemporary wars:broad implications for health and social well-being. Social Science \& Medicine, 55, 175-190.

Rogers, E. M. (1995). Diffusion of innovations (4th ed., p. 518). New York: Free Press.

Rogers, E. M. (2003). Diffusion of Innovations (5th ed). Free Press.

Ruuska, I., \& Teigland, R. (2009). Ensuring project success through collective competence and creative conflict in public-private partnerships - A case study of Bygga Villa, a Swedish triple helix e-government initiative. International Journal of Project Management, 27(4), 323-334. http://dx.doi/10.1016/j.ijproman.2008. 02.007

Shao, X., \& Siponen, M. (2011). Consumer acceptance and use of information technology: Adding consumption theory to UTAUT2," Proceedings > Proceedings of SIGSVC Workshop. Sprouts: Working Papers on Information Systems, 11(157). http://sprouts.aisnet.org/11-157

Shao, X., \& Siponen, M. (2011). Consumer Acceptance and Use of Information.

Sheppard, B. H., Hartwick, J., \& Warshaw, P. R. (1988). The theory of reasoned action: A meta-analysis of past research with recommendations for modifications and future research. Journal of Consumer Research, 15, $325-343$.

Slade, E., Williams, M., \& Dwivedi, Y. (2013). Extending UTAUT2 to explore consumer adoption of mobile payments'. Proceedings of the UK Academy for Information Systems Conference, March 19-20th, Oxford.

Taylor, S., \& Todd, P. (1995). Assessing IT Usage: The Role of Prior Experience. MIS Quarterly, 19(4).

Technology: Adding consumption theory to UTAUT2," Proceedings > Proceedings of SIGSVC Workshop. Sprouts: Working Papers on Information Systems, 11(157). http://sprouts.aisnet.org/11-157

Thompson, R. L., \& Higgins, C. A., et al. (1991). Personal Computing: Toward a Knowledge Management: Theory \& Practice. Malaysia.

Top 10 Most Dangerous Countries in the World. (2013). Top 10 Most Dangerous Countries in the World 2013. Retrieved August 4, 2013, from http://toptenstore.blogspot.com/2013/01/top-10-most-dangerous-countriesin.html

Venkatesh, V., \& Davis, F. D. (2000). A theoretical extension of the technology acceptance model: Four 
longitudinal Field Studies. Management Science, 46(2), 186-204.

Venkatesh, V., \& Morris, M. G., et al. (2003). User acceptance of information technology: Toward a unified view1. MIS Quarterly, 27(3), 425-478.

Venkatesh, V., Sykes, T., \& Zhang, X. (2011). Just what the doctor ordered: A revised UTAUT for EMR system adoption and use by doctors (pp. 1-10). Proceedings of the 44th Hawaii International Conference on System Sciences, Kauai, HI.

Walela, P. (2009). Relevance Of Usability To Development Of Cellular Technology (Master's thesis, Strathmore University).

Wang, H., \& Rubin, B. L. (2004). Embedding e-finance in e-government: a new e-government framework. Electronic Government, an International Journal, 1(4), 362-373. http://dx.doi.org/10.1504/EG.2004.005912

Wang, H., \& Yang, H. (2005). The Role of Personality Traits in UTAUT Model under Online Stocking. Contemporary Management Research, 1(1), 69-82.

Wang, Y. S., \& Shih, Y. W. (2009). Why do people use information kiosks? A validation of the Unified Theory of Acceptance and Use of Technology. Government Information Quarterly, 26(1), 158-165.

Wu, Y.-L., \& Tao, Y.-H., et al. (2007). Using UTAUT to explore the behavior of $3 G$ mobile communication users. Industrial Engineering and Engineering Management, 2007 IEEE International Conference on.

Yahya, M., Nadzar, F. Masrek, N. \& Abd Rahman, B. (2011). Determinants of UTAUT in measuring useracceptance of E-syariah portal in syariah courts in Malaysia. Proceedings of the 2nd International Research Symposium in Service Management, July 26-30, 2011, Yogyakarta, Indonesia (pp. 242-250). Retrieved from http://irssm.upnyk.ac.id/userfiles/file/papers/031.pdf.

Yayla, A., \& Hu, Q. (2007). User Acceptance of E-Commerce Technology: A Meta-Analytic Comparison Of Competing Models. Retrieved from http://is2.1se.ac.uk/asp/aspecis/20070192.pdf

\section{Copyrights}

Copyright for this article is retained by the author(s), with first publication rights granted to the journal.

This is an open-access article distributed under the terms and conditions of the Creative Commons Attribution license (http://creativecommons.org/licenses/by/3.0/). 